From the foregoing I believe that the status quo of Apatela remains virtually unchanged since my paper in Papilio, iii, I 16, I 883. The list there given by the of unidentified names can only be safely changed to-day by the elimination of two of Harris' posthumous names based on larvae: Ulmi Harris, being based on larvae belonging to morula, as Prof. Smith tells us, and is therefore a synonym ; while pruni Harris may be used for the species called by me clarescens, since the evidence is that Guenée's clarescens is not mine, although exactly what it is not made out unquestionably. As before, the "future monographer" whom we are all expecting ( $\mathrm{I}$ wish $\mathrm{I}$ had the naming of him) must busy himself with the question of what Guenée really described under the names: spinigera, telum, interrupta, and longa, and he will do well to reject interrupta altogether, as founded on a figure which, in this difficult genus, will hardly be admitted as a proper basis for a description and name. It will shorten his labors by so much. He will have also to decide what Abbot intends by his plates of aceris and hastulifera, and he will have an easier task to make out Harris' remaining name salicis. I shall be glad if the other names in the catalogue, which are mainly based on my identifications, receive his confirmation. But he must conscientiously compare Guenée's text with the material, inasmuch as names derive their authority from literature, not from labelled specimens, however convenient these may be as a substitute for the somewhat arduous labor of making a specimen "function" to a description.

Note--Since finishing this article I have received a letter from $\mathrm{Mr}$. Harrison G. Dyar, who kindly informs me that the larva figured in Harris' Correspondence under the name salicis, belongs to oblinita. If there is any difference between our northern species and oblinita as figured by Abbot, we have a name in salicis for the northern form. Dr. Thaxter called my attention to material collected by him in Florida, but I was not able to find any points of specific distinction as compared with northern oblinita.

\title{
PREPARATORY STAGES OF COSMOSOMA AUGE LINN.
}

BY HARRISON G. DYAR, NEW YORK.

A full fed larva was found at Lake Worth, Florida, late in December and eggs were obtained from several female moths found flying over the flowers of some vines of Mikania scandens growing in the swamp. I am much indebted to Mr. F. Kinzel of Palm Beach, who has kindly sent me leaves of the food plant every few days, and thus enabled me to raise the larvae and observe their stages.
Eggs. Rather low conoidal with flat base; smooth, shining, translucent, waxy white, faintly tinged with yellow; no marks under a hand lens. Under a half-inch objective the reticulations are linear, rounded, hexagonal, irregular, even four-sided, scarcely raised. Diameter $0.8 \mathrm{~mm}$., height $0.6 \mathrm{~mm}$. Usually laid singly on the young leaves of the food plant. Duration of this stage eight days.

Stage I. Head colorless, eyes black, 
mouth brown; width $.3 \mathrm{~mm}$. Body entirely colorless, the hairs single, rather long, white; anal feet rather large, divergent; length $2.5 \mathrm{~mm}$. Later certain of the dorsal hairs (of tubercle ii) and all the warts become blackish. After feeding the body is greenish from the food showing by transparency, the head, thoracic feet and joint 13 slightly yellowish. Warts normal, single haired, iv behind the spiracle, vi absent, an oval dusky leg-plate with several hairs; on joints 3 and 4 tubercles ia, ib and iia from a single area, iib weak, remote, iii and $\mathrm{v}$ absent, vi with two hairs. On joint $\mathrm{I} 3 \mathrm{i}$, ii and iii from a single area, iv and $v$ from $a$ single area, the anal plate with ro hairs.

Stage II. Head yellow, shining, ocelli black; width $.4 \mathrm{~mm}$. Body whitish, yellow at the ends as in the mature larva; warts all black, neatly defined, several, haired, arranged as in the mature larva, the subprimaries present, normal. Hair black and white mixed, the white the most numerous, spinulated; warts iv and $v$ on joints 5 and II a little larger than elsewhere, the hairs, however, all alike. Leg-plates pale.

Stage III. Head .6 mm., whitish, the ends of the body yellow; warts black, all much as before, the hairs quite dense, but not at all obscuring the body, variously curved, from six to ten arising from each wart.

Stage IV. Head $.8 \mathrm{~mm}$. The same, the warts distinct, neatly defined; hair a little thicker laterally on joints 5 and $I I$, indicating the tufts, but no plumed hairs present.

Stage $V$. Head $1.2 \mathrm{~mm}$. There is no change; length about $14 \mathrm{~mm}$.

Stage VI. Head $1.7 \mathrm{~mm}$. Similar to the mature larva except for the absence of the side tufts, though warts iv and $v$ on joints 5 and II bear an unusual number of black hairs, thus serving to suggest the tufts. The hairs are all alike, black and white, of even length, abundant, but fine, not obscuring the body. A distinct orange mark on joint I2 before the spiracle. A few long hairs anteriorly.
Stage VII. Mature larva. Head yellow, ocelli black, mouth brown; width $2.4 \mathrm{~mm}$. Body yellowish on joints $3,4, \mathrm{I} 2$ and $\mathrm{I} 3$, joint 12 most distinctly so, as also the feet; warts and spiracles black; i to iii normal, iv small but distinct, behind the spiracles, $\mathbf{v}$ and vi normal, none large. Hair dense, fine, of even length, black, and white mixed, the white predominating, the appearance consequently pale gray, sparsely dashed with black. On joints 5 and II dense concolorous tufts laterally, the same length as the other hairs and also white and black, but heavily feathered, the black ones plumed; these tufts arise from warts iii and iv. On the thorax there is one large wart above the stigmatal wart, but it is not elongated nor of unusual size; a few long hairs from it overhang the head. On joint 2 the cervical shield has two tiny warts on each side, a wart at the edge, a stigmatal and a subventral wart. Skin translucent, without marks.

Cocoon. Large, elliptical, attached only by one side to the supporting object as in Halisidota caryae, composed of silk and the larval hairs, transparent, regular, light yellow, intermixed with black plumed hairs; size $17 \times 9 \mathrm{~mm}$.

Pupa. Rounded, shaped as in Halisidota, the incisures not movable. All pale yellow, spiracles, eyes and a row of dorsal marks black. The pupa skin is very thin, but all the essential points indicate an Arctian affinity, not Lymantriid as stated in Ent. Amer. (vol. i, p. 86) where the editor was evidently misled by the transparent skin of the empty pupa. His statement should be reversed. Imago in 21 days.

Note on Dionychopus.-In Psyche for July Mr. R. A. Cooley questions the accuracy of the results of Dr. W. Donitz in respect to the structures in Dionychopus niveus Men. which could be capable of producing a sound heard by Dr. Donitz. This has led me to examine the species, and I believe that $\mathrm{Mr}$. Cooley is entirely correct. The spiny patch is present on the under side of the fore wing 

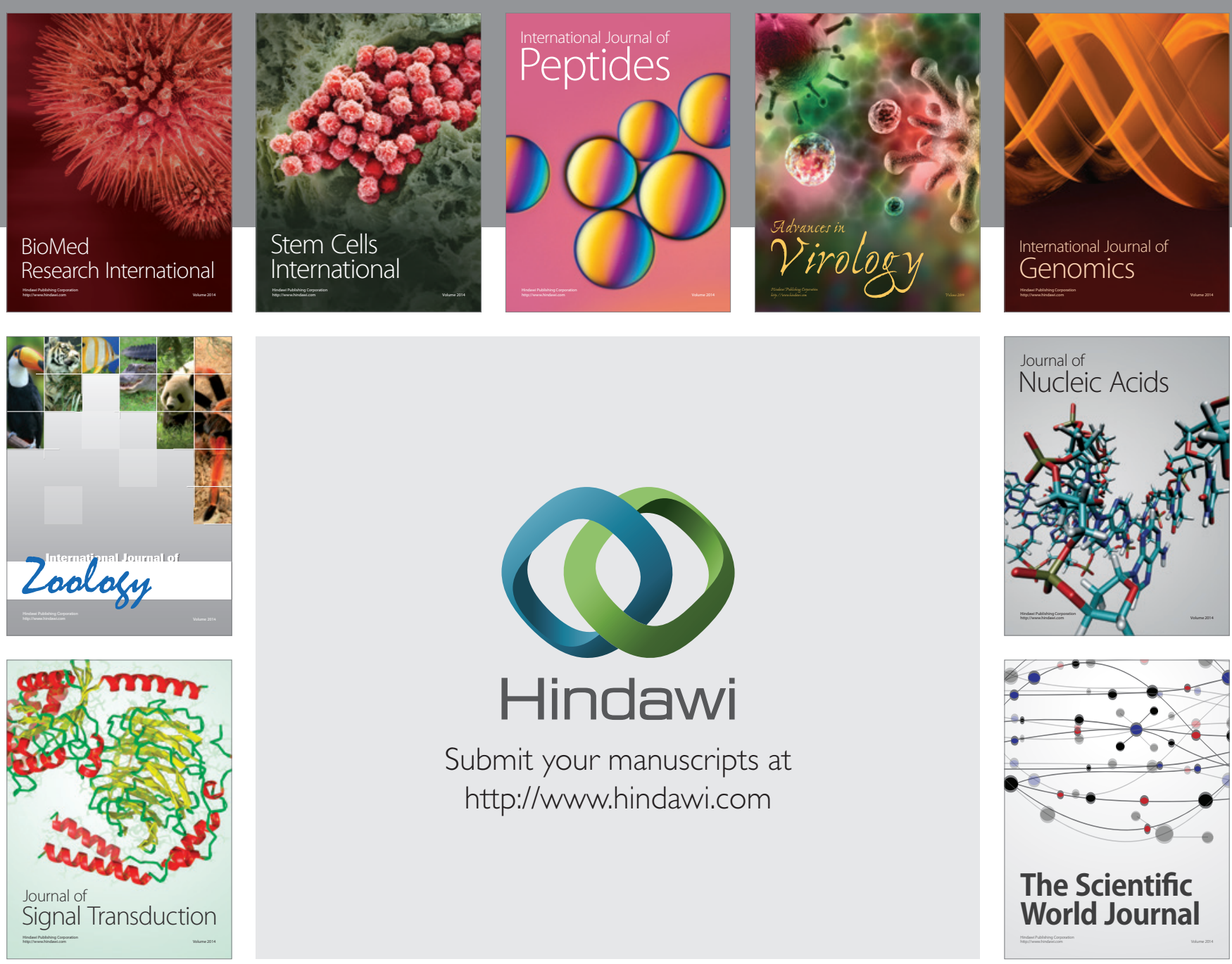

Submit your manuscripts at

http://www.hindawi.com
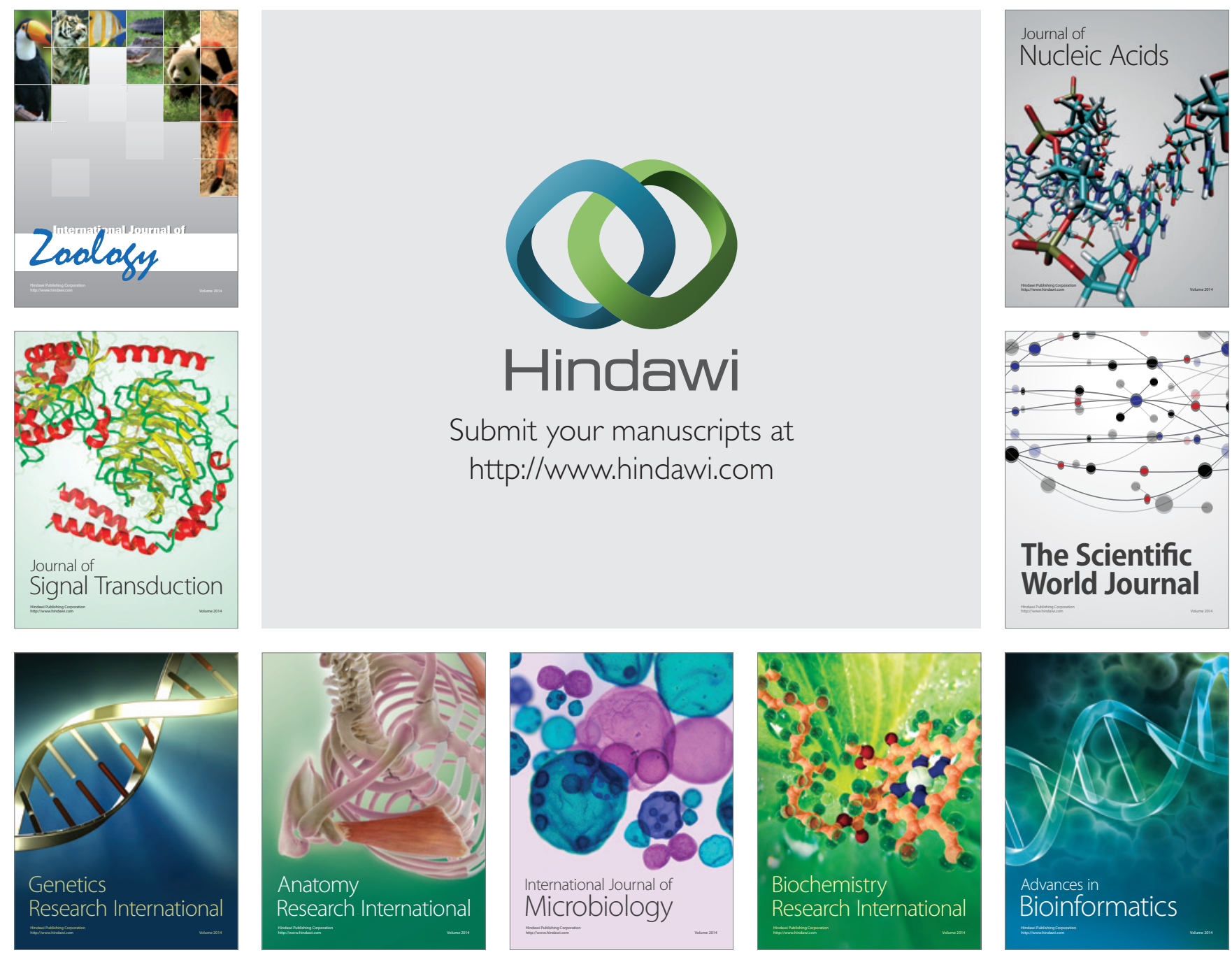

The Scientific World Journal
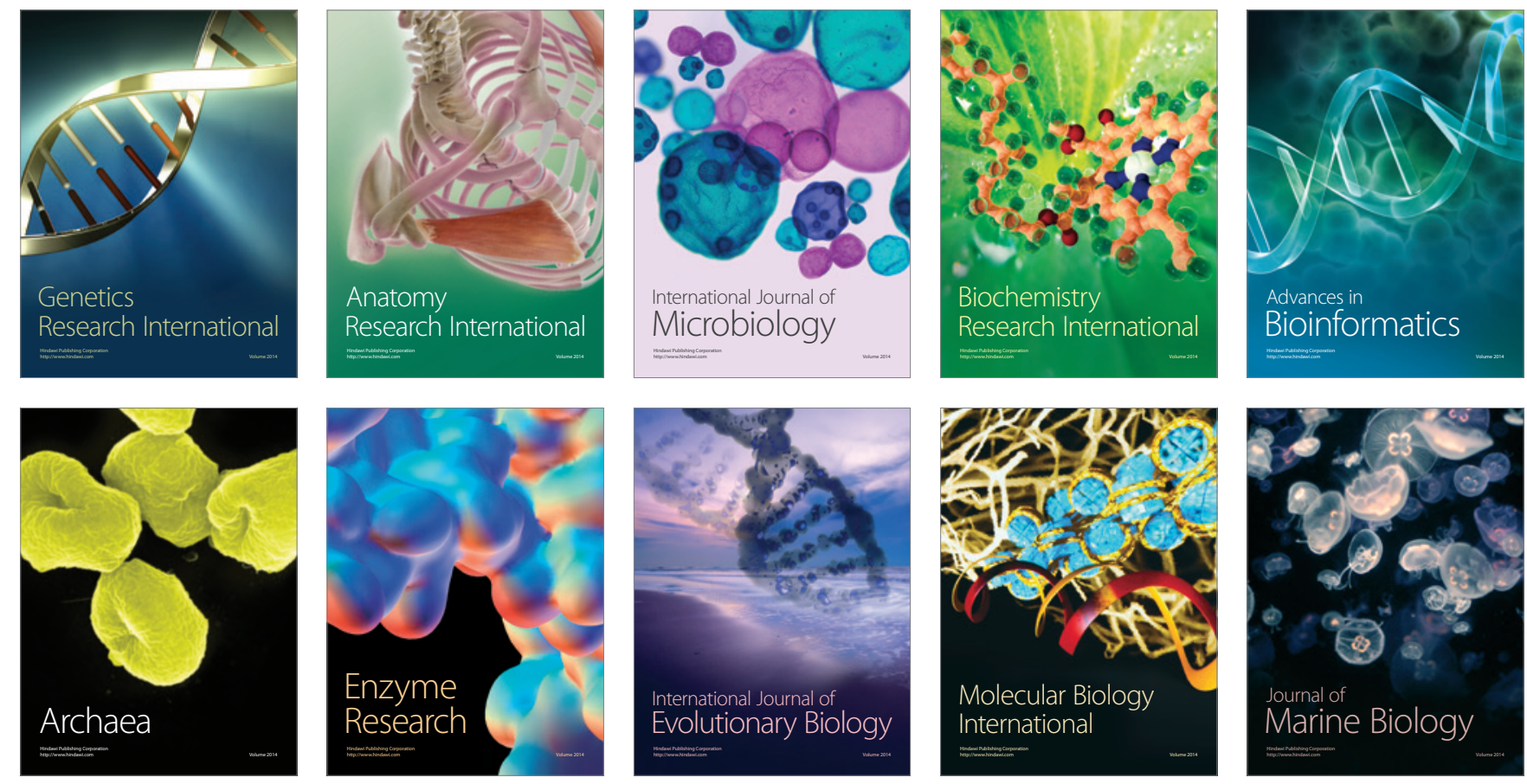